\title{
Evaluation of mental health and illness reports issued by a military health board in Turkey
}

\section{Sağlık kurulunda verillen ruh sağlığı ve hastalıkları ile ilgili askeri raporların değerlendirilmesi}

\author{
Filiz Özsoy ${ }^{1}$, Müiberra Kullu²
}

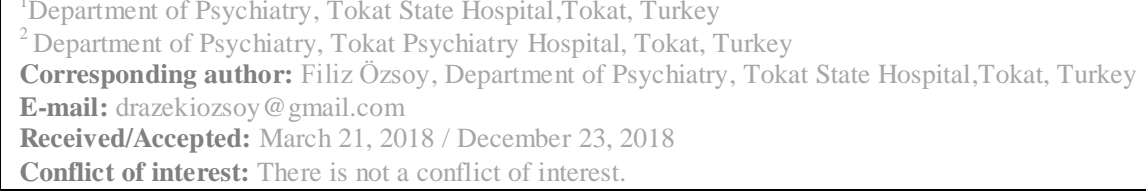

\section{SUMMARY}

Objective: In Turkey, compulsory military service applies to all male citizens from twenty to forty years of age. This study was carried out to investigate the distribution of cases diagnosed and reported on mental health and illness among young adult males presenting for health examinations during recruitment for compulsory military service.

Method: In this retrospective study, health reports of 2,153 people presenting for the military service examination by Health Board of Tokat State Hospital between January $1^{\text {st }}, 2017$ and December $31^{\text {st }}, 2017$ were examined.

Results: One hundred and two cases out of 2,153 applicants (4.72\%) were diagnosed with a disease related to mental health and diseases. Seventeen patients referred to Department of Mental Health and Illness because of their past mental illnesses, on the other hand, were not diagnosed with a psychiatric disorder. The most frequent diagnoses were intelligence deficits in 24 cases $(23.5 \%)$, neurotic disorders in 20 cases (19.6\%), adjustment disorders in 16 cases (15.84\%), antisocial personality disorders in 12 cases $(11.7 \%)$, bipolar affective in 9 cases $(8.82 \%)$ and psychosis in 8 cases $(7.84 \%)$.

Conclusions: The results of the present study, which examined the mental health reports given to military personal and personal candidates who presented to Tokat State Hospital to obtain a board report for their mental health status, could contribute to the management of adult mental health and illness practice in Turkey. In addition, the results could help in organization of future board reports.

Keywords: Military, Health board, Mental health and illness, Psychiatric disorders.

\section{ÖZET}

Amaç: Türkiye'de 20-40 yaş arasındaki erkekler zorunlu askerlik hizmeti yapmaktadır. Bu çalışma, zorunlu askerlik hizmeti için sağlık muayenelerine alınan genç erişkin erkekler arasında ruh sağlı̆̆ı ve hastalıkları ile ilgili tanı alıp rapor verilen olguların dağılımını incelemek amacıyla yapılmıştır.

Yöntem: Retrospektif olarak yapılan bu çalışmada 1 Ocak 2017-31 Aralık 2017 tarihleri arasında Tokat Devlet Hastanesi Sağlık Kurulu'na askerlik muayenesi için müracaat eden 2153 kişinin raporları incelenmiştir.

Bulgular: Toplam 2153 başvurudan 102 (\%4.72) olguya ruh sağlığı ve hastalıkları ile ilgili bir hastalık tanısı verilmiştir. Ruh sağlığı ve hastalıkları ile ilgili geçirilmiş rahatsılıkları ya da önceki yıllara ait raporları olduğu için ruh sağlığı ve hastalıkları bölümüne sevk edilen 17 kişinin ise tanı koyduracak düzeyde psikiyatrik hastalığı tespit edilmemiştir. En sık konulan tanılar 24 (\%23.5) olgu ile zeka yetersizlikleri, 20 olgu (\%19.6) nevrotik bozukluk, 16 olgu (\%15.84) uyum bozukluğu, 12 olgu (\%11.7) antisosyal kişilik bozukluğu, 9 olgu (\%8.82) bipolaraffektif bozukluk ve 8 olguya ise (\%7.84) psikoz olarak bulunmuştur.

Sonuç: Sağlık kuruluna başvuran ve ruhsal rahatsızlığı sebebiyle rapor verilen askeri personel ve personel adaylarına verilen raporların incelendiği bu çalışma ile erişkin ruh sağlığı ve hastalıklarıpratiğine katkıda bulunacağı ve askeri personel ve askeri personel adaylarına ait raporların düzenlenmesine faydalı olabileceği düşünülmüştür.

Anahtar sözcükler: Asker, sağlık kurulu, ruh sağlı̆̆ı ve hastalıları. 


\section{INTRODUCTION}

According to Military Service Law of Republic of Turkey (Law No: 1111), military service is a legal right and obligation for men at 20-40 years of age in Turkey ${ }^{1}$. Based on Article 107 of Statutory Decree No. 669 within the context of State of Emergency and Decree No. 29804 of August 17, 2016 published in The Official Gazette about Methods and Principles for Transfer of Gülhane Military Medicine Academy and other military hospitals, all hospitals, dispensaries, and similar affiliated health units of Gülhane Military Medicine Academy under the command of Health Commands of Turkish Military Forces (TSK) and affiliated health institutions of General Command of Gendarmerie have been transferred to Ministry of Health ${ }^{2}$.

According to this decree, all mental health and illness physicians working in authorized health institutions throughout Turkey have been given the authority and responsibility to conduct examinations of incumbents for military service eligibility and to give mental health reports. Examination of incumbents is carried out based on Regulation for Turkish Armed Forces Health Ability. This regulation has been prepared to lay the principles of health abilities of Turkish Armed Forces personnel and personnel candidates. Disorders have been categorized into (A), (B) and (D) groups and subgroups within them. Treatment and recovery conditions, on the other hand, are classified within (C) group. Group " $A$ " means that illness table is improving and may not cause a clinically important health problem, and sequel will not negatively affect functionality. Group "B" generally includes past clinical tables which could affect functionality and they constitute the conditions which render applicants (obligatory military service incumbents including reserve officer candidates) ineligible for military service. However, they can be recruited for military service after healthy people in case of mobilization if their clinical table remain the same. Officers, petty officers and specialist gendarmes in active duty with a category "B" report may continue to their services in their classes (though as noncombatants) or may change their classes. However, a "B" report means ineligibility for military service in Turkish Armed Forces for specialist petty officers and contractual military specialist/ranker. Which service an active soldier (officer, petty officer and specialist gendarme) judged to be in " $\mathrm{B}$ " category will be allocated to is determined by Classification Tables
No: 1 and 2, which were prepared according to applicant's Force (Land, Naval or Air), class and rank and were given in Regulation. Group " $\mathrm{C}$ " defines treatment, monitoring and recovery situations of illnesses. Incumbents categorized in Group "D” (obligatory military service personnel) do not take part in military service even in the case of mobilization, and active duty personnel classified in this category retire ${ }^{3}$.

Different number of people apply to medical health boards of hospitals. During the judgment process of an applicant, health boards take information regarding mental health from applicant himself and, when necessary, from his relatives, perform some psychometric tests, consider previous medical reports, monitor person as inpatient, or carry out follow-up interviews. All these activities necessitate a considerable amount of work by health board members. It has been known that duties involving preparation of health reports in some hospitals take more time of involved physicians than they spend for monitoring and treatment of patients in their polyclinics and services.

Reports of both military health boards and medical boards for disability are important data sources because they involve detailed examinations and record keeping. There are several studies in literature dealing with reports of medical boards for disability which examined mental health and illness, neurology, ear, nose, throat and eye illnesses ${ }^{4-7}$.However, to our best knowledge, there has been no study in Turkish literature about mental pathologies and their frequencies in reports of military health boards. The aim of the present study was to determine the frequency of psychiatric illness diagnoses in a population of Turkish Armed Forces personnel and personnel candidates who presented to Health Board of Tokat State Hospital for medical report.

\section{MATERIAL AND METHODS}

Necessary approvals were taken for the present study from Local Ethic Board for Non-Invasive Studies in Gaziosmanpaşa University and Tokat Provincial Health Directorate. The study included people who applied to Military Medical Board of Tokat State Hospital in January 1, 2017December 31, 2017 period for the purposes of examination for military service, for obtaining health report as petty officers in active duty and contractualspecialist petty officer/commando, for contract renewal checking, for eligibility for general military service, reserve officer, military 
student, civil servant in army and temporary duty and appointment abroad. Analysis of the records showed that a total of 2,158 people applied to Military Medical Board for the health report in the year 2017. Since the study included adult age group, five military personnel relatives younger than 18 years of age who applied for health report for appointment were excluded. Of 2,153 adults, 102 had previous reports for various mental illnesses, and their reports were also evaluated. Since the data in automation system were missing or inadequate, these evaluations were carried out through inspection of Health Board's files. Purpose of application, diagnoses made and conclusion for eligibility for the duty were recorded for all cases. Evaluations were made based on "Regulations for Turkish Armed Forces Health Ability" published in The Official Gazette. For statistical analyses, SPSS software (Version 18.0) was used.

\section{RESULTS}

Results showed that a total of 2,158 applications were made to Military Health Board of Tokat State Hospital in 2017. Five cases $(0.3 \%)$ under the age of 18 were excluded. Six people were referred to other health institutions for diagnosis and four people who applied for determination of whether the health problem of applicant was due to military servicewere also excluded. Of the remaining 2,143 applications, four $(0.18 \%)$ were women and 2,150 (99.82\%) were men. Reasons for application to Military Health Board were listed in Table 1. Leading reason was to obtain health report for contractual military specialist/ranker/commando. For these applications, 954 people $(44.5 \%)$ were assigned "completely healthy" report, while 722 people $(33.7 \%)$ were given Category "A" illness diagnoses and 467 people (21.8\%) Category "B" or "D" illness diagnoses. "Eligible for duty" report, which was the reason for application, was assigned to 1,653 cases (77.1\%), "Not eligible for duty" report was given to 370 cases $(17.3 \%)$ while "Postponement for a certain time" conclusion was made for 111 cases $(5.2 \%)$, "Approved for the appointment" report was assigned for seven cases $(0.3 \%)$ and "Not approved for appointment" conclusion was reached for two cases $(0.1 \%)$. A total of 119 cases $(5.55 \%)$ had a mental illness diagnosis. Psychiatric illness was not diagnosed in 17 cases referred to Mental Health and Illness Department because of their past mental illness diagnoses or reports; in other words, they were mentally healthy.

Table 1. Reasons for application to Military Health Board of Tokat State Hospital

\begin{tabular}{lccc} 
Reason for application & Number & \% \\
\hline Contractualspecialist petty officer/commando & 987 & 46.1 & 19.9 \\
Petty officers in active duty & 427 & 17.6 \\
Roll call for army private & 378 & 6.9 \\
Eligibility for military service & 147 & 4.1 \\
Reserve officer & 88 & 2.5 \\
Contract renewal & 54 & 0.7 \\
Receptee & \multicolumn{2}{c}{15} & 0.1 \\
Civil servant in Turkish Armed Forces & \multicolumn{2}{c}{3} & 0.4 \\
Eligibility as military student & \multicolumn{2}{c}{9} & 0.4 \\
Eligibility for appointment & 9 & 0.5 \\
Eligibility for abroad duty & 11 & 0.7 \\
Contractual gendarmerie & 15 & \\
\hline
\end{tabular}


When the reasons for application of cases who had mental illness diagnoses were examined, three $(2.5 \%)$ were for contractual specialistranker/commando, $46 \quad(38.7 \%)$ for regular health checking for military service, 51 $(42.9 \%)$ for eligibility for military service, 10 $(8.4 \%)$ for Reserve Officer, seven $(5.9 \%)$ for deployment of soldier on active duty, one $(0.8 \%)$ for determination of whether the health problem of applicant was due to military serviceand one $(0.9 \%)$ for examination and treatment. Diagnoses made for mental health or illness were given in Table 2. Twenty four cases $(20.16 \%)$ who had mental illness diagnoses, including 17 cases who had previous mental illness diagnoses or reports and referred to Mental Health and Illness Department, were concluded to be "eligible for the duty" for which application was made, while 63 cases $(53 \%)$ were concluded to be "not eligible for the duty". In addition, 14 cases (11.76\%) had "postponement for a certain time" and 17 cases $(14.28 \%)$ were concluded "eligible under the supervision of Rehabilitation Counseling Center (RCC)". One case $(\% 0.8)$ could not be diagnosed and was referred to another health institution.

Table 2.Psychiatric diagnoses and their percentages

Diagnosis made

Number

$\%$

Intelligence deficits

Limited mental capacity

$10 \quad 9.8$

Slight mental retardation

12

11.7

Moderate mental retardation

1

0.98

Heavy mental retardation

1

0.98

\section{Neurotic disorders}

Depressive disorder

Anxiety disorder

Chronic neurosis

Obsessive compulsive disorder

Panic disorder

Prolonged mourning reaction

Adjustment disorder

Adjustment disorder in the past

16

6.86

\begin{tabular}{lcc}
\hline Bipolar affective disorder & 9 & 8.82 \\
\hline Psychotic disorder & 8 & 7.84 \\
\hline Antisocial personality disorder & 12 & 11.70 \\
\hline Substance use in the past & 2 & 1.96 \\
\hline Substance addiction & 2 & 1.96 \\
\hline Speech disorder & 2 & 1.96 \\
\hline
\end{tabular}




\section{DISCUSSION}

In this retrospective study, it was found that out of 2,153 cases who applied to Military Health Board, $119(5.55 \%)$ had mental illness diagnoses. The most common reasons for the application of military personnel or candidates to the Board were regular checks for the eligibility to military service and eligibility examination of active soldiers to continue their services. The most common diagnoses were intelligence deficits, adjustment disorders and neurotic disorders in descending order.

Twenty-four (20.16\%) out of 119 people who took mental disorder diagnoses were assigned "eligible for the duty" report and they included 17 people who were referred to Mental Health and Illness Department because of their previous health illnesses and diagnoses but found to have no mental illnesses. Sixty-three cases $(53 \%)$ had "not eligible" report while 14 cases had "postponement for a certain time for the duty" and 17 cases had "eligible under the supervision of RCC" report. Diagnosis could not be made for a case and he was referred to another health institution.Out of 17 cases who were assigned "eligible under the supervision of RCC", nine cases (53\%) had adjustment disorder, four (23\%) adjustment disorder in the past, two (12\%) neurosis in the past and two (12\%) anxiety disorder diagnoses. To our best knowledge, there has been no comprehensive study in Turkish literature dealing with mental disorder diagnoses of army personnel who applied to medical boards. Studies about medical boards frequently dealt with applications of the disabled to medical boards and prevalence of disability. In a study involving 5.670 people who applied to Medical Board for Disability, 795 cases (14.02\%) were issued "mentally disabled" report. The most commonly made diagnoses were intelligence deficits (52.2\%), schizophrenia (18.4\%) and depression-dysthymia (7.1\%) [4].In another study involving people who applied to Medical Board for Disability, 151 out of 1,036 applicant (14.6\%) were found to have mental disorders, the most common ones being mental retardation $(25.8 \%)$, schizophrenia (20.5\%) and depression (17.9\%) ${ }^{8}$.Similar to abovementioned studies, intelligence deficits were the most common diagnosis made in the present study. In Turkey, mentally disabled people account for $29.2 \%$ of people registered in National Database for the Disabled. When the people who had intelligence deficit diagnosis were examined in detail, it was found that $9.8 \%$ had limited mental capacity, $11.7 \%$ had slight mental retardation, $0.98 \%$ had moderate mental retardation, and $0.98 \%$ had heavy mental retardation. It can be suggested that these frequencies could be different from other studies due to the facts that only adult people over 18 years of age applying for a report were included in the study, that frequencies of people who did not apply for a medical report were not known and that some of the applicants had previous medical reports.

Anxiety, major depressive disorder, obsessive spectrum disorder, trauma and stress related disorders, somatoform, dissociative eating disorders and subcategories of them are listed neurotic disorders mentioned in Article 16 of Turkish Armed Forces Health Ability Code about mental health and illness.Neurotic disorders are second most diagnosed illness group after mental retardation. Of these diagnoses, two army personnel and personnel candidate with anxiety disorder were assigned "eligible for military service under supervision of RCC", two cases were given "postponement of service for a given time" and one case was given "ineligible for military service" reports. Two of the eight cases who had chronic neurotic disorder were assigned "postponement of service for a given time", other two were given "eligible for military service under the supervision of RCC", and remaining four were assigned "ineligible for military service" reports. Two cases with depressive disorder diagnosis were given "postponement of service for a given time", and one was assigned "ineligible for military service" reports. Cases with compulsive disorder, panic disorder and prolonged mourning reaction had "postponement of service for a given time" report. In Medical Board for Disabilityreports mentioned in literature, especially depressive disorder and anxiety disorder were much more common. In a study carried out by a university hospital, out of 3,176 applications to Medical Board for Disability, 318 cases were given psychiatric illness diagnoses, and 73 of them $(23 \%)$ had depressive disorder and 34 (20.7\%) had anxiety disorder ${ }^{9}$.

In our study group, the most frequent diagnosis was adjustment disorder. Two cases with this disorder were assigned "eligible for military service", nine cases were assigned "eligible for military service under supervision of RCC", one case was given "postponement of service for a given time" and four cases were given "ineligible 
for military service" reports. Some applicants had previous adjustment disorder diagnoses. Four of them were assigned "eligible for military service" and another four were given "eligible for military service under supervision of RCC" reports. In a study carried out in Psychiatry Clinic of Gülhane Military Medicine Academy (GATA), diagnosis groups were identified for a total of 1,311 inpatients in the clinic. Among the leading diagnoses were schizophrenia in 248 cases $(18.9 \%)$ and antisocial personality disorder in 240 patients (18.3\%). Adjustment disorder was another frequent disorder with 140 cases (10.6\%) 10

Frequencies of psychosis (schizophrenia, schizoaffective disorder and other psychotic disorders), commonly observed disorder in Medical Board for Disability reports, and bipolar affective disorder were relatively low in the present study. Yildiz et al. ${ }^{4}$ found that mental retardation was the most common disorder in Medical Board for Disability reports, followed by schizophrenia, schizoaffective disorder and other psychotic disorders. Bipolar affective disorder followed psychosis in incidence rate. It could be stated that lack of data about patients who did not apply for a health report, previous report application by some patients and the fact that applications for military health report belonged to men only could change the incidence rates of mental disorders.

All cases in the study group who were given antisocial personality disorder diagnosis were given "ineligible for military service" report. A study in literature retrospectively examined 1,482 cases referred for legal examination, and found that 448 cases $(30.2 \%)$ had antisocial personality disorder diagnosis ${ }^{11}$. The same study revealed that antisocial personality disorder was closely associated with repeating crime commitment and substance use. In another study conducted on army privates, tendency to use violence in cases with antisocial personality disorder was investigated using violence grading scale. Tendency to use violence was high in all cases, though the severity of the tendency varied among individuals ${ }^{12}$.

There were two cases in our study group who used active substance, and they were given "ineligible for military service" report. It has been mentioned in literature that substance use was associated with repeating commitment of violence and crime tendency ${ }^{13}$. Especially high repeating crime behavior was reported in cases using substance.

The most common reasons for the application of cases who had mental illness diagnosis to Military Health Board were for checking whether they were eligible for military service and for their first regular check-up for military service. Mental illnesses and associated disabilities are multidimensional problems involving person, family, society and working life. Therefore, one might think that individuals with mental illnesses may experience difficulties in their military services. To our best knowledge, there has been no study conducted in Turkey about mental illness reports of military health boards so far. Health board services given to military personnel in hospitals are one of the common services given by many mental health specialists and assistants, and it is necessary for these personnel to be familiar with these services. Studies carried out on these services could help prepare regulations based on Turkish Armed Forces Health Ability Regulations in terms of both establishment of a healthy database about the mental pathologies and evaluation of data collected.

\section{REFERENCES}

1. Türkiye Cumhuriyeti Askerlik Kanunu. Kanun Numarası:1111, Kabul Tarihi:21/6/1927. Resmi Gazete 1927; 8:631-35.

2. Gülhane Askeri Tip Akademisi ve Asker Hastanelerinin Devrine İlişkin Usul ve Esaslar Hakkında Karar. Resmi Gazete 2016; 29804, 9109.

3. Türk Silahlı Kuvvetleri, Jandarma Genel Komutanlığı ve Sahil Güvenlik Komutanlığı Sağlik Yeteneği Yönetmeliği. Resmi Gazete 2016; 29885, 9431.

4. Yıldız M, Özsoy F, Batmaz S, Songur E, Karakülah K. Engelli sağlik kurulunda verilen ruh sağlığı ve hastalıkları engelli raporlarının değerlendirilmesi, Cukurova Med J 2016; 41:2538.

5. Çabalar M, Demirtaş Tatlıdede A, Yazar T, Güveli B, Yayla V. Nörolojik hastalıkların özürlülük derecelerinin sağlik kurulunda değerlendirilmesi, Bakırköy Tıp Derg., 2011; 1426.

6. Sayın İ, Erdur Ö, Topçu İ, Kayhan FT. Sağlık kuruluna Özürlülük tespiti ve diğer nedenlerle başvuran olgularda kulak burun boğaz patolojileri ve sıklıkları: gözlemsel bir çalışma, KBB Forum, 2011;10:87-91. 
7. Ceyhan D, Yaşar T, Demirok A, Çınal A, Esmer O, Batur M. Sağlık kurulu raporlarına göre Van bölgesinde görme özürlülük nedenleri, Turkish J Ophthalmol 2012; 42:131-4.

8. Demirci K, Akpinar A, Ozdamar Unal G, et al. Investigation of psychiatricpathologies in subjectswhoapplytothehealth board, Bull Clinic Psychopharmacol 2015; 137:25-1.

9. Aslan E, Şimşek N. Psikiyatrik Bozukluklara Bağlı Engellilik Hali; Üniversite Hastanesi Deneyimi, Klinik Psikiyatri, 2017; 20:197-202.

10. Evrensel A, Balıbey H, Tarhan N. Bir Üniversite Hastanesi Psikiyatri Servisinde Yatarak Tedavi Gören Hastaların Yatış Süreleri ve Klinik Özellikleri: Bir Y1llık İnceleme, Med Science 2016; 5:371-83.

11. Bolu A, Toygar M, Pan E, Erdem M, Ünlü G, Balıkçı A. Bir eğiitm hastanesi psikiyatri kliniğinde adli olguların değerlendirilmesi; 5 yıllık inceleme, Gülhane Tıp Derg. 2014; 56:1-4.

12. Erdem M, Özdemir B, Çelik C, Balıkcı A, Türker T, Nahit N. Antisosyal Kişilik Bozukluğu Olgularının Şiddet Suçu Niteliğine Göre Mizaç ve Karakter Özellikleri, Klinik Psikiyatri, 2010; 13:113-8.

13. Öncü F, Soysal H, Uygur N. Suç işlemiş şizofrenlerde zorunlu klinik tedavi sonrası yineleyici suç, 38. Ulusal Psikiyatri Kongresi Bildiri Özet Kitab1, 27-28 Ekim 2002, Marmaris. 